\title{
Aqueous-phase hydrogenation and hydroformylation reactions catalyzed by a new water-soluble [rhodium]-thioligand complex
}

\author{
S. Paganelli ${ }^{\mathrm{a}, *}$, O. Piccolo $^{\mathrm{b}}$, P. Pontini $^{\mathrm{a}}$, R. Tassini ${ }^{\mathrm{a}}$, V.D. Rathod ${ }^{\mathrm{a}}$ \\ a Dipartimento di Scienze Molecolari e Nanosistemi, Università Ca' Foscari Venezia, Calle Larga S. Marta 2137, 30123 Venezia, Italy \\ b SCSOP, Via Bornò 5, 23896 Sirtori, Italy
}

\section{A R T I C L E I N F O}

\section{Article history:}

Received 27 March 2014

Received in revised form 9 May 2014

Accepted 27 May 2014

Available online 3 July 2014

\section{Keywords:}

Rhodium

Dihydrothioctic acid

Thioligand

Aqueous catalysis

Hydrogenation

Hydroformylation

\begin{abstract}
A B S T R A C T
$\mathrm{Rh}(\mathrm{DHTANa})$ is a new water-soluble catalyst easily obtained by mixing in water the catalytic precursor $[\mathrm{Rh}(\mathrm{COD}) \mathrm{Cl}]_{2}$ and the dihydrothioctic acid sodium salt (DHTANa). This catalyst showed to be very active in the hydrogenation of unsaturated substrates as 2-cyclohexen-1-one, the biomass-derived furfural and acetophenone. In this last case the catalytic system obtained by using as water-soluble ligand (R)(DHTANa) afforded (R)-1-phenylethanol with very modest enantioselectivity. Rh(DHTANa) was active also in the aqueous biphase hydroformylation of styrene producing exclusively the two corresponding aldehydes with $80-86 \%$ selectivity toward the branched aldehyde 2-phenylpropanal. This new catalytic system was easily recycled in both hydrogenation and hydroformylation processes and no leaching phenomenon was observed.
\end{abstract}

(c) 2014 Elsevier B.V. All rights reserved.

\section{Introduction}

Homogeneous catalysis is an efficient tool to carry out a chemical process in a very active and selective way but the major drawback of the homogeneous process is the separation of the expensive catalyst from the product mixture that requires an energy intensive process such as distillation. In recent years the use of metallic species with suitable ligands has allowed chemists to carry out reactions in biphasic systems so permitting an easy separation of the used catalyst, confined in a phase different from that of reagents and products, and its re-use in recycling experiments; in particular, the use of both water as co-solvent for biphasic reactions and easily recyclable water-soluble catalysts are highly desirable for the realization of green processes [1-4]. In the last years natural compounds, such as aminoacids, peptides, proteins and sugars have been used as ligands for metallic species active as catalysts [5-9]. In this context, some years ago we reported highly efficient and chemoselective hydroformylation [10-12] and hydrogenation [8] reactions using water-soluble complexes derived from the interaction between $\mathrm{Rh}(\mathrm{CO})_{2}$ (acac) or $[\operatorname{Ir}(\mathrm{COD}) \mathrm{Cl}]_{2}$, respectively, with human serum albumin (HSA). Previous studies, carried out by us on the catalytic system Rh/HSA, showed an outstanding correspondence between the surface distribution of $\mathrm{Rh}$ and $\mathrm{S}$

\footnotetext{
* Corresponding author. Tel.: +39 0412348592; fax: +39 0412348517

E-mail address: spag@unive.it (S. Paganelli).
}

atoms of the protein, therefore we hypothesized that the metal atom mainly interacts with the sulphur atoms [13,14]: the great affinity of "soft" metals, such as rhodium, for the thiolic group is well known [15]. As a matter of fact many rhodium complexes modified with thioligands have been successfully employed in catalytic reactions in homogeneous phase in organic solvents [16-23]. Our goal was to study catalytic processes in the presence of water-soluble sulphur containing ligands: in particular we used some thio-oligopeptides as ligands in the rhodium catalyzed hydroformylation of styrene [14]. More recently, we turned our attention to simple and cheap water-soluble low molecular weight thioligands such as the aminoacid (L)-Cysteine and [(S)-1-[(S)-3mercapto-2-methylpropanoyl]pyrrolidine-2-carboxylic acid] (sold as a pharmacologically active ACE inhibitor, named Captopril ${ }^{\circledR}$ ). Both ligands were capable of promoting efficiently the hydrogenation process in the presence of Rh or Ir catalytic precursors and, at the same time, allowing an easy recovery and recycling of the water-soluble catalytic complexes [24]. In these last months we addressed our research to the use of a very simple molecule, e.g. dihydrothioctic acid (DHTA), the reduced form of thioctic acid (THA), which presents two - $\mathrm{SH}$ groups capable, in principle, to work as a bidentate ligand for the rhodium atom (Fig. 1). The presence of another functional group, $-\mathrm{COOH}$, in the molecule, when it is salified, might favor the solubility in water of the Rh complex but also create a potential third bonding site for the metallic species. Finally, as this molecule presents a chiral center and the corresponding enantiomers are easily prepared from a commercially 
<smiles>O=C(O)CCCCC(S)CCS</smiles>

Fig. 1. Thioctic acid (THA) and dihydrothioctic acid (DHTA).

available enantiopure precursor, we could set out to evaluate the enantioselectivity in the hydrogenation of suitable substrates catalyzed by rhodium-(DHTA sodium salt) complex, from now on named $\mathrm{Rh}(\mathrm{DHTANa})$.

\section{Experimental}

\subsection{Materials and methods}

$[\mathrm{Rh}(\mathrm{COD}) \mathrm{Cl}]_{2}, 2$-cyclohexen-1-one, furfural, acetophenone and styrene were Aldrich products. Thioctic acid and (R)-thioctic acid were a generous gift of Prochifar s.r.l. (Milan) and Sintactica s.r.l. Cassina De' Pecchi (Milan), respectively. GC analyses were carried out on an Agilent 6850 A gaschromatograph (HP1 column $30 \mathrm{~m} \times 0.32 \mathrm{~mm} \times 0.25 \mu \mathrm{m}$ ) and GC-MS analyses were performed by using an Agilent MS Network 5937 (HP-5MS column $30 \mathrm{~m} \times 0.25 \mathrm{~mm} \times 0.25 \mu \mathrm{m})$. Enantiomeric excess of 1 phenylethanol $(\mathbf{X})$ was determined by GC equipped with a cyclodex B (Agilent) capillary column $(30 \mathrm{~m} \times 0.32 \mathrm{~mm}$ I.D. $\times 0.25 \mu \mathrm{m}$ thickness): initial $T_{50}{ }^{\circ} \mathrm{C}$; initial $t 1.1 \mathrm{~min}$; solvent delay $4.48 \mathrm{~min}$; $\mathrm{T}$ ramp $1.3^{\circ} \mathrm{C} / \mathrm{min}$; final $T_{150}{ }^{\circ} \mathrm{C}$. (R)-configuration was determined by polarimetric measurements by using a Perkin Elmer 241 polarimeter $\left([\alpha]^{20}{ }_{D}=+43, c=5\right.$ in $\mathrm{CH}_{3} \mathrm{OH}$ for pure (R)-X). ICP-MS analysis was performed by using an Agilent 7500a-Series instrument.

\subsection{Dihydrothioctic acid sodium salt (DHTANa) preparation}

Dihydrothioctic acid (DHTA) was prepared as described [25].

Thioctic acid ( $510 \mathrm{mg}, 2.5 \mathrm{mmol}$ ) was dissolved in a solution of $210 \mathrm{mg}(2.5 \mathrm{mmol})$ of $\mathrm{Na}_{2} \mathrm{CO}_{3}$ in $12 \mathrm{~mL}$ of $\mathrm{H}_{2} \mathrm{O}$ and cooled to $0{ }^{\circ} \mathrm{C}$ in an ice bath. $\mathrm{NaBH}_{4}(190 \mathrm{mg}, 5 \mathrm{mmol})$ was added slowly and the temperature kept below $4{ }^{\circ} \mathrm{C}$ while stirring for an additional $2 \mathrm{~h}$. The reaction mixture was acidified with $2 \mathrm{M} \mathrm{HCl}$ to $\mathrm{pH} 1$ and extracted with $\mathrm{CHCl}_{3}(3 \times 10 \mathrm{~mL})$. The combined organic phases were dried over $\mathrm{MgSO}_{4}$ and filtered. Evaporation of the solvent yielded $507 \mathrm{mg}$ (98\%) of DHTA as a clear colorless oil. The oil was maintained under nitrogen at low temperature $\left(-20^{\circ} \mathrm{C}\right) .{ }^{1} \mathrm{HNMR}$ $\left(\mathrm{CDCl}_{3}\right): \delta 10.1$ (bs, $\left.1 \mathrm{H}, \mathrm{OH}\right), 2.89(\mathrm{~m}, 1 \mathrm{H}, \mathrm{S}-\mathrm{CH}), 2.7\left(\mathrm{~m}, 2 \mathrm{H}, \mathrm{S}-\mathrm{CH}_{2}\right)$, $2.4\left(\mathrm{t}, J=7.1 \mathrm{~Hz}, 2 \mathrm{H}, \mathrm{CH}_{2}-\mathrm{COOH}\right), 1.92-1.4\left(\mathrm{~m}, 8 \mathrm{H},\left(\mathrm{CH}_{2}\right)_{4}\right), 1.36(\mathrm{t}$, $J=7.9,1 \mathrm{H}, \mathrm{SH}), 1.31$ (d, $J=7.6,1 \mathrm{H}, \mathrm{SH}) .{ }^{13} \mathrm{C}-\mathrm{NMR}: \delta 180.4(\mathrm{COOH})$, $43.1\left(\mathrm{SH}-\mathrm{CH}_{2}-\mathbf{C H}_{2}-\mathrm{CH}\right), 39.7\left(\mathbf{C H}_{\mathbf{2}}-\mathrm{COOH}\right), 39.1\left(\mathbf{C H}_{\mathbf{2}}-\mathrm{CH}-\mathrm{SH}\right)$,
34.3 (CH-SH), $26.9\left(\mathrm{CH}-\mathrm{CH}_{2}-\mathbf{C H}_{2}\right), 24.7\left(\mathbf{C H}_{2}-\mathrm{CH}_{2}-\mathrm{COOH}\right), 22.7$ $\left(\mathrm{CH}_{2}-\mathrm{SH}\right)$. The corresponding sodium salt DHTANa was obtained by treatment of $507 \mathrm{mg}$ ( $2.46 \mathrm{mmol})$ of DHTA with one equivalent of $\mathrm{Na}_{2} \mathrm{CO}_{3}$ dissolved in $10 \mathrm{~mL}$ of deaerated $\mathrm{H}_{2} \mathrm{O} .{ }^{1} \mathrm{HNMR}\left(\mathrm{H}_{2} \mathrm{O} / \mathrm{D}_{2} \mathrm{O}\right)$ : $\delta 2.92(\mathrm{~m}, 1 \mathrm{H}, \mathrm{S}-\mathrm{CH}), 2.6\left(\mathrm{~m}, 2 \mathrm{H}, \mathrm{S}-\mathrm{CH}_{2}\right), 2.08(\mathrm{t}, J=7.2 \mathrm{~Hz}, 2 \mathrm{H}$, $\mathrm{CH}_{2}-\mathrm{COONa}$ ), $1.9-1.78\left(\mathrm{~m}, 2 \mathrm{H}, \mathrm{HSCH}_{2} \mathbf{C H}_{2} \mathrm{CHSH}\right), 1.72-1.3(\mathrm{~m}, 10 \mathrm{H}$, $\left.\left(\mathrm{CH}_{2}\right)_{4}, 2 \mathrm{SH}\right)$.

The aqueous solution obtained was then used for the preparation of the Rh(DHTANa) complex. In the same way (R)-(DHTANa) was prepared starting from (R)-thioctic acid.

\section{3. $R h(D H T A N a)$ catalyst preparation}

The catalytic complex $\mathrm{Rh}(\mathrm{DHTANa})$ was prepared in situ by reacting, at room temperature under a nitrogen purge, $[\mathrm{Rh}(\mathrm{COD}) \mathrm{Cl}]_{2}(12.4 \mathrm{mg}, 0.025 \mathrm{mmol})$ with a solution of dihydrothioctic acid sodium salt (DHTANa) $(10.3 \mathrm{mg}, 0.5 \mathrm{mmol})$ in $5 \mathrm{ml}$ of deaerated water until complete dissolution of the complex. ${ }^{1} \mathrm{HNMR}$ $\left(\mathrm{H}_{2} \mathrm{O} / \mathrm{D}_{2} \mathrm{O}\right): \delta 3.61(\mathrm{~m}, 1 \mathrm{H}, \mathrm{S}-\mathrm{CH}), 3.12\left(\mathrm{~m}, 2 \mathrm{H}, \mathrm{S}-\mathrm{CH}_{2}\right), 2.08(\mathrm{t}$, $\left.J=7.2 \mathrm{~Hz}, 2 \mathrm{H}, \mathrm{CH}_{2}-\mathrm{COONa}\right), 1.9-1.78\left(\mathrm{~m}, 2 \mathrm{H}, \mathrm{HSCH}_{2} \mathbf{C H}_{2} \mathrm{CHSH}\right)$, $1.72-1.3\left(\mathrm{~m}, 10 \mathrm{H},\left(\mathrm{CH}_{2}\right)_{4}, 2 \mathrm{SH}\right)$. By comparing the ${ }^{1} \mathrm{HNMR}$ of the free ligand DHTANa and the corresponding rhodium complex $\mathrm{Rh}$ (DHTANa) we can observe a clear shift of the protons present on the carbon atoms originally bound to the thiolic groups, so indicating a possible chelation of Rh to the $\mathrm{S}$ atoms.

In the same way (R)-Rh(DHTANa) was prepared starting from (R)-(DHTANa). The complex Rh(DHTANa $)_{2}$ was prepared at the above reaction conditions but by using a double amount of the water-soluble thioligand DHTANa.

\subsection{Hydrogenation experiments}

All reactions were carried out following the procedure below described for the hydrogenation of 2-cyclohexen-1-one (I). Experimental details for all the hydrogenations are reported in Tables $1-4$.

\subsubsection{Hydrogenation of 2-cyclohexen-1-one (I)}

In a Schlenk tube, $1 \mathrm{~mL}$ of a $0.005 \mathrm{M}$ solution of Rh(DHTANa) in deaerated water and $480 \mathrm{mg}$ ( $5.0 \mathrm{mmol}$ ) of 2-cyclohexen-1-one (I) in $2 \mathrm{~mL}$ of deaerated $\mathrm{H}_{2} \mathrm{O}$ were stirred under nitrogen. The Schlenk tube was then transferred into a $150 \mathrm{~mL}$ stainless steel autoclave under nitrogen, pressurized with $\mathrm{H}_{2}$ and stirred for the due time at $60{ }^{\circ} \mathrm{C}$ (Table 2). The reactor was then cooled to room temperature and the residual gases released. Diethyl ether was added to the reaction mixture and the organic phase was separated, dried on $\mathrm{Na}_{2} \mathrm{SO}_{4}$ and analyzed by GC and GC-MS. The catalytic aqueous phase was recycled for further experiments after addition of fresh of 2-cyclohexen-1-one (I).

Table 1

Aqueous biphasic hydrogenation of cycloehex-2-en-1-one (I) catalyzed by Rh(DHTANa).

\begin{tabular}{|c|c|c|c|c|c|c|c|}
\hline Run & Sub/cat. (molar ratio) & $t(\mathrm{~h})$ & Conv. (\%) & II yield (\%) & III yield (\%) & IV yield (\%) & $\mathrm{TOF}^{\mathrm{a}}$ \\
\hline 1 & 500 & 4 & 99 & 95 & 4 & nd & 124 \\
\hline $2^{\mathrm{b}}$ & 500 & 4 & 99 & 90 & 9 & nd & 124 \\
\hline $3^{b}$ & 500 & 4 & 99 & 93 & 6 & nd & 124 \\
\hline $4^{\mathrm{b}}$ & 500 & 4 & 84 & 82 & 2 & nd & 105 \\
\hline 5 & 1000 & 4 & 69 & 68 & 1 & nd & 173 \\
\hline $6^{\mathrm{b}}$ & 1000 & 4 & 69 & 68 & 1 & nd & 173 \\
\hline $7^{b}$ & 1000 & 4 & 55 & 54 & 1 & nd & 138 \\
\hline 8 & 1000 & 6 & 99 & 96 & 3 & nd & 165 \\
\hline $9^{b}$ & 1000 & 6 & 99 & 97 & 2 & nd & 165 \\
\hline $10^{\mathrm{b}}$ & 1000 & 6 & 99 & 97 & 2 & nd & 165 \\
\hline
\end{tabular}

Substrate $=5 \mathrm{mmol} ; \mathrm{T}=60^{\circ} \mathrm{C} ; \mathrm{p}\left(\mathrm{H}_{2}\right)=2 \mathrm{MPa} ; \mathrm{H}_{2} \mathrm{O}=2 \mathrm{ml}$; toluene $=1 \mathrm{ml}$. $\mathrm{nd}=$ not detected in the reaction mixture.

a $\mathrm{TOF}=(\mathrm{mol} / \mathrm{mol}$ cat. $) \mathrm{h}^{-1}$.

b Experiment carried out by using the catalytic phase recovered from the previous run. 
Table 2

Hydrogenation of cycloehex-2-en-1-one (I) catalyzed by Rh(DHTANa) in pure water.

\begin{tabular}{|c|c|c|c|c|c|c|c|}
\hline Run & $\mathrm{pH}_{2}(\mathrm{MPa})$ & $t(\mathrm{~h})$ & Conv. (\%) & II yield (\%) & III yield (\%) & IV yield (\%) & $\mathrm{TOF}^{\mathrm{a}}$ \\
\hline 1 & 2 & 4 & 99 & 95 & 4 & nd & 248 \\
\hline $2^{\mathrm{b}}$ & 2 & 4 & 99 & 94 & 5 & nd & 248 \\
\hline $3^{\mathrm{b}}$ & 2 & 4 & 99 & 94 & 4 & nd & 248 \\
\hline 4 & 1 & 4 & 99 & 90 & 9 & nd & 248 \\
\hline $5^{\mathrm{b}}$ & 1 & 4 & 99 & 93 & 6 & nd & 248 \\
\hline $6^{\mathrm{b}}$ & 1 & 4 & 99 & 95 & 4 & nd & 248 \\
\hline 7 & 1 & 2 & 97 & 94 & 3 & nd & 485 \\
\hline $8^{\mathrm{b}}$ & 1 & 2 & 82 & 80 & 2 & nd & 410 \\
\hline $9^{\mathrm{b}}$ & 1 & 2 & 80 & 78 & 2 & nd & 400 \\
\hline $10^{\mathrm{b}}$ & 1 & 2 & 60 & 58 & 2 & nd & 300 \\
\hline $11^{\mathrm{c}}$ & 2 & 18 & 3 & 2 & 1 & nd & 2 \\
\hline
\end{tabular}

Substrate $=5 \mathrm{mmol}$; substrate $/ \mathrm{Rh}($ molar ratio $)=1000 / 1 ; T=60^{\circ} \mathrm{C} ; \mathrm{H}_{2} \mathrm{O}=2 \mathrm{ml}$. nd $=$ not detected in the reaction mixture.

a $\mathrm{TOF}=(\mathrm{mol} \mathbf{I} / \mathrm{mol}$ cat. $) \mathrm{h}^{-1}$.

b Experiment carried out by using the catalytic phase recovered from the previous run.

c Experiment carried out in the presence of Rh(DHTANa $)_{2}$.

Table 3

Aqueous biphasic hydrogenation of furfural (V) catalyzed by Rh(DHTANa).

\begin{tabular}{lllllll}
\hline Run & $t(\mathrm{~h})$ & Conv. $(\%)$ & VI yield $(\%)$ & VII yield $(\%)$ & VIII yield $(\%)$ & TOF $^{\text {a }}$ \\
\hline $1^{\text {b }}$ & 6 & 38 & 38 & nd & nd & 32 \\
2 & 6 & 69 & 69 & nd & nd & 58 \\
$3^{\text {c }}$ & 6 & 67 & 67 & nd & nd & 56 \\
$4^{\text {c }}$ & 6 & 40 & 40 & nd & nd & 33 \\
5 & 16 & 99 & 99 & nd & nd & 31 \\
$6^{c}$ & 16 & 98 & 98 & nd & nd & 31 \\
$7^{\text {c }}$ & 16 & 99 & 99 & nd & nd & 31 \\
$8^{\text {c }}$ & 16 & 71 & 71 & nd & nd & 22 \\
\hline
\end{tabular}

Substrate $=2.5 \mathrm{mmol}$; substrate $/ \mathrm{Rh}($ molar ratio $)=500 / 1 ; T=60^{\circ} \mathrm{C} ; \mathrm{p}\left(\mathrm{H}_{2}\right)=2 \mathrm{MPa}$; Solvent: $\mathrm{H}_{2} \mathrm{O} / \mathrm{THF}(2 \mathrm{ml} / 1 \mathrm{ml})$. nd = not detected in the reaction mixture.

a $\mathrm{TOF}=(\mathrm{mol} \mathbf{V} / \mathrm{mol} \mathrm{cat}) \mathrm{h}^{-1}$.

b Solvent: $\mathrm{H}_{2} \mathrm{O}(2 \mathrm{ml})$.

c Experiment carried out by using the catalytic phase recovered from the previous run.

Table 4

Aqueous biphasic hydrogenation of acetophenone (IX) catalyzed by Rh(DHTANa).

\begin{tabular}{llllll}
\hline Run & Sub/cat. (molar ratio) & Conv. (\%) & X yield (\%) & TOF $^{\mathrm{a}}$ & ee\% $^{\mathrm{b}}$ (Conf.) \\
\hline 1 & 500 & 70 & 70 & 18 & $15(\mathrm{R})$ \\
$2^{\mathrm{c}}$ & 500 & 57 & 57 & 14 & $8(\mathrm{R})$ \\
$3^{\mathrm{c}}$ & 500 & 30 & 30 & 8 & $4(\mathrm{R})$ \\
4 & 100 & 95 & 95 & 5 & $5(\mathrm{R})$ \\
$5^{\mathrm{c}}$ & 100 & 65 & 65 & 3 & $5(\mathrm{R})$ \\
\hline
\end{tabular}

Substrate $=4 \mathrm{mmol} ; T=60^{\circ} \mathrm{C} ; p\left(\mathrm{H}_{2}\right)=2 \mathrm{MPa} ; t=20 \mathrm{~h} ; \mathrm{H}_{2} \mathrm{O}=2 \mathrm{ml}$.

a $\mathrm{TOF}=(\mathrm{mol} \mathbf{I X} / \mathrm{mol} \mathrm{cat}) \mathrm{h}^{-1}$.

b Determined by GC equipped with cyclodex B (Agilent) capillary column $\left(30 \mathrm{~m} \times \mathrm{m} 0.32 \mathrm{~nm}\right.$ I.D: $\times 0.25 \mu \mathrm{m}$ thickness); $\left([\alpha]_{\mathrm{D}}{ }^{20}=+43, \mathrm{c}=5\right.$ in $\left.\mathrm{CH}_{3} \mathrm{OH}\right)$.

c Experiment carried out by using the catalytic phase recovered from the previous run.

\subsection{Hydroformylation of styrene (XI)}

In a Schlenk tube, $1 \mathrm{~mL}$ of a $0.005 \mathrm{M}$ solution of $\mathrm{Rh}$ (DHTANa) in deaerated water, $520 \mathrm{mg}(5.0 \mathrm{mmol})$ of styrene $(\mathbf{X I}), 1 \mathrm{~mL}$ of deaerated $\mathrm{H}_{2} \mathrm{O}$ and $2 \mathrm{~mL}$ of toluene were stirred under nitrogen. The Schlenk tube was transferred into a $150 \mathrm{~mL}$ stainless steel autoclave under nitrogen, pressurized to $8 \mathrm{MPa}$ with syngas $\left(\mathrm{CO} / \mathrm{H}_{2}=1\right)$ and heated at $80^{\circ} \mathrm{C}$ for $18 \mathrm{~h}$ (see Table 5). The reactor was then cooled to room temperature and the residual gases released. The organic phase was separated and dried on $\mathrm{Na}_{2} \mathrm{SO}_{4}$. The two isomeric aldehydes XII and XIII were characterized by GC and GC-MS. The aqueous phase was then used as catalyst for a consecutive recycling experiment after addition of fresh styrene and toluene.

\section{Results and discussion}

Thioctic acid is known as a very useful natural antioxidant which is both fat- and water-soluble and contains a carboxyl group and two sulfur atoms. In nature exists in two forms, such as cyclic disulfide (oxidized form, TA) or as open chain with the name of dihydrothioctic acid, which shows two sulfydryl groups in position 6 and 8 (reduced form, DHTA) and the two forms are, however, easily interconvertible via redox reactions [26]. DHTA can be easily obtained from its oxidized form by $\mathrm{NaBH}_{4}$ reduction [25]; as such, it is not soluble in water but its sodium salt (DHTANa) is highly water-soluble and, in principle, could represent a good and cheap chelating agent for rhodium catalytic precursors. To our knowledge this simple molecule has never been used as ligand to carry out aqueous biphasic catalytic hydrogenation and hydroformylation processes, therefore we started our research by studying the hydrogenation of 2-cyclohexen-1-one (I); this $\alpha, \beta$-unsaturated molecule might represent a useful model substrate to evaluate both activity and selectivity of the new water-soluble catalyst Rh(DHTANa) (Scheme 1, Table 1). The catalytic precursor was prepared in situ by mixing in deaerated water the dihydrothioctic acid sodium salt and $[\mathrm{Rh}(\mathrm{COD}) \mathrm{Cl}]_{2}$, maintaining a one to one molar ratio between $\mathrm{Rh}$ and the ligand. A first experiment was carried out in the biphase system water/toluene at $60^{\circ} \mathrm{C}$ and $2 \mathrm{Mpa}$ of $\mathrm{H}_{2}$ for $4 \mathrm{~h}$, by using a

Table 5

Aqueous biphasic hydroformylation of styrene (XI) catalyzed by rhodium complexes modified with DHTANa.

\begin{tabular}{|c|c|c|c|c|c|c|c|}
\hline Run & Catalyst & Conv. (\%) & XII yield (\%) & XIII yield (\%) & XIV yield (\%) & XII/XIII & TOF $^{\mathrm{a}}$ \\
\hline 1 & Rh(DHTANa) & 99 & 83 & 16 & nd & 5.2 & 55 \\
\hline $2^{b}$ & & 97 & 82 & 15 & nd & 5.5 & 54 \\
\hline $3^{b}$ & & 99 & 84 & 15 & nd & 5.6 & 55 \\
\hline $4^{b}$ & & 99 & 80 & 18 & nd & 4.4 & 55 \\
\hline 5 & $\mathrm{Rh}(\mathrm{DHTANa})_{2}$ & 4 & 4 & nd & nd & & 2 \\
\hline $6^{\mathrm{b}}$ & & 99 & 86 & 13 & nd & 5.6 & 55 \\
\hline $7^{b}$ & & 99 & 83 & 16 & nd & 5.2 & 55 \\
\hline $8^{b}$ & & 96 & 81 & 15 & nd & 5.4 & 53 \\
\hline
\end{tabular}

Substrate $=5 \mathrm{mmol}$; substrate $/ \mathrm{Rh}$ (molar ratio) $=1000 / 1 ; T=80^{\circ} \mathrm{C} ; \mathrm{p}(\mathrm{CO})=p\left(\mathrm{H}_{2}\right)=4 \mathrm{MPa} ; t=18 \mathrm{~h} ; \mathrm{H}_{2} \mathrm{O}=2 \mathrm{ml}$; toluene $=1 \mathrm{ml}$. nd $=$ not detected in the reaction mixture

a $\mathrm{TOF}=(\mathrm{mol} \mathrm{XI} / \mathrm{mol}$ cat. $) \mathrm{h}^{-1}$.

b Experiment carried out by using the catalytic phase recovered from the previous run. 
<smiles>C=CCCCCC1CCC(O)CC1</smiles>

Scheme 1. Hydrogenation of 2-cyclohexen-1-one (I).<smiles>CC(=O)c1ccccc1</smiles>

Scheme 3. Hydrogenation of acetophenone (IX).

substrate/Rh molar ratio 500/1: conversion was $99 \%$ and selectivity to cyclohexanone (II) was about 96\%, being also cyclohexanol (III) formed, even if in a very small amount (run 1, Table 1). Same results were obtained in two consecutive recycling experiments and only a low decrease of activity, but not of selectivity, was observed when the catalyst was reused for the third time (84\% conversion, $98 \%$ selectivity) (run 4 , Table 1 ). Due to the high activity of this catalytic system we carried out some hydrogenations at the above reaction conditions but using a substrate/Rh molar ratio 1000/1: in this case a conversion decrease, using the same reaction time, was observed (69\%) but the selectivity to cyclohexanone (II) was almost 99\% (run 5 , Table 1). The catalytic aqueous phase was used in a consecutive recycling experiment and both conversion and selectivity remained unchanged. Disappointingly, a second recycling reaction showed a decrease of the catalytic activity: conversion was 55\% but selectivity to cyclohexanone (II) remained very high (run 7, Table 1). In order to increase the substrate conversion, the reaction time was prolonged to $6 \mathrm{~h}$. Conversion in both first experiment, carried out in the presence of fresh catalyst, and in two consecutive recycling reactions was practically quantitative and also selectivity toward cyclohexanone (II) was always $98 \%$ (run $8-10$, Table 1 ). It is important to note that the catalytic system Rh(DHTANa) showed to be very stable ad no leaching phenomenon was observed. As a matter of fact, the organic phase recovered after the first hydrogenation reaction (run 8 , Table 1 ) was used as catalyst in the homogeneous hydrogenation of undec-1-ene in toluene: after $4 \mathrm{~h}$ at $60^{\circ} \mathrm{C}$ and $2 \mathrm{MPa}$ of $\mathrm{H}_{2}$, undecane was not formed at all. Moreover, analysis of the same organic phase, carried out by ICP-MS, indicated that not more than $1 \mathrm{ppm}$ of rhodium was extracted from the aqueous to the organic phase.

Due to the good solubility in water of 2-cyclohexen-1-one (I) we decided to carry out the reaction in a homogeneous aqueous system using water as the sole reaction solvent (Table 2). Very good results were obtained at $60^{\circ} \mathrm{C}$ and $2 \mathrm{Mpa}$ of $\mathrm{H}_{2}$ for $4 \mathrm{~h}$ and by using a $1000 / 1$ substrate/Rh molar ratio: conversion was always $99 \%$ in both first reaction and in two recycling experiments and cyclohexanone (II) was the prevailing product (95\% selectivity) (runs $1-3$, Table 2 ). Due to the high activity of the catalytic system in simple water, we studied the optimization of the reaction conditions lowering $\mathrm{H}_{2}$ pressure to 1 MPA: again, conversion was almost quantitative and it maintained practically unchanged also in two recycling experiments (runs 4-6, Table 2). Then we decided to decrease the reaction time to $2 \mathrm{~h}$ : the first experiment gave a 97\% conversion and a $97 \%$ selectivity to cyclohexanone (II); disappointingly, two consecutive recycling experiments showed a lower catalytic activity, 82 and $80 \%$ conversion, respectively, but the selectivity to cyclohexanone (II) did not change (runs 8 and 9, Table 2). Noteworthy, when the reaction was carried out by using the catalytic precursor containing two moles of the water soluble thioligand per rhodium atom, $\mathrm{RH}(\mathrm{DHTANa})_{2}$, conversion was very low (18\%) after $18 \mathrm{~h}$ at $60{ }^{\circ} \mathrm{C}$ and $2 \mathrm{Mpa}$ of $\mathrm{H}_{2}$ (substrate/Rh molar ratio $=1000 / 1$ ) (run 11 , Table 2): the presence of two moles of the chelating thioligand surely makes more difficult the coordination of the unsaturated substrate to rhodium and the following oxidative addition of hydrogen.

The results obtained in the hydrogenation of 2-cyclohexen-1one (I) spurred us to investigate the activity of this new catalytic system in the hydrogenation of furfural (FAL) (V) as the design of novel and ecofriendly catalysts, at low cost, for the efficient transformation of natural resources or biomass-derived platform chemicals is a very promising approach [27-29]. Lignocellulose is a potential sustainable and renewable organic carbon source and in particular FAL is a promising building block for fuels and chemicals. It is usually obtained by acid-catalyzed dehydration of pentoses, five carbon sugars, such as xylose and arabinose, or produced by fast pyrolysis of biomass. However, the high oxygen content makes FAL unstable against condensation and polymerization reactions that provide undesirable storage properties. Hydrogenation of FAL (V) to furfuryl alcohol (FOL) (VI) is a method used to avoid these undesired reactions [30,31]. FOL is also a very important intermediate in the chemical industry since it is widely used in the production of synthetic fibers, thermostatic resins, fine chemicals, etc. [32-36]. It is mainly produced by hydrogenation of FAL ( $\mathbf{V})$ either in gas or liquid phase. Gas-phase hydrogenation of furfural is a high energy demanding process due to the high temperatures necessary for vaporizing FAL [37]; moreover, a big amount of byproducts is formed. On the other hand the liquid-phase process requires solvent and high pressures of hydrogen but it is characterized by a lower energy consumption and, generally, higher selectivities to furfuryl alcohol are reached $[35,38]$. Recently furfural has been hydrogenated to furfuryl alcohol in water, under very mild reaction conditions, by using polymer stabilized $\mathrm{Ru}(0)$ nanoparticles in the presence of cyclodextrins [39]. To our knowledge, only few examples of hydrogenation of FAL to FOL catalyzed by homogeneous metal complexes are reported in the literature [40-43] but none of them describes the use of rhodium compounds. First, FAL $(\mathbf{V})$ was hydrogenated in sole water as reaction solvent but after $6 \mathrm{~h}$ at $60^{\circ} \mathrm{C}$ and $2 \mathrm{MPa}$ of $\mathrm{H}_{2}$ by using a substrate/Rh molar ratio 500/1 conversion to furfuryl alcohol (VI) was only $38 \%$ (run 1 , Table 3)(Scheme 2). The reaction was then carried out in the system water/tetrahydrofurane (THF) so allowing a better phase contact between the water containing catalyst and the organic substrate. By using the above reaction conditions, conversion was $69 \%$ and, again, furfuryl alcohol (VI) was the only product formed (run 2, Table 3). Activity and selectivity remained practically unchanged in a recycling experiment while a further reused of the catalyst afforded only $40 \%$ conversion but, again, furfuryl alcohol (VI) was

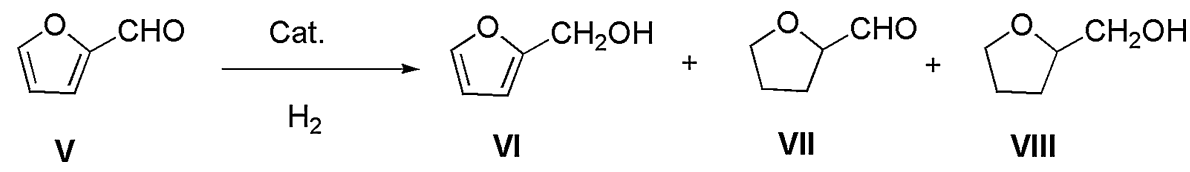

Scheme 2. Hydrogenation of furfural (FAL) (V). 


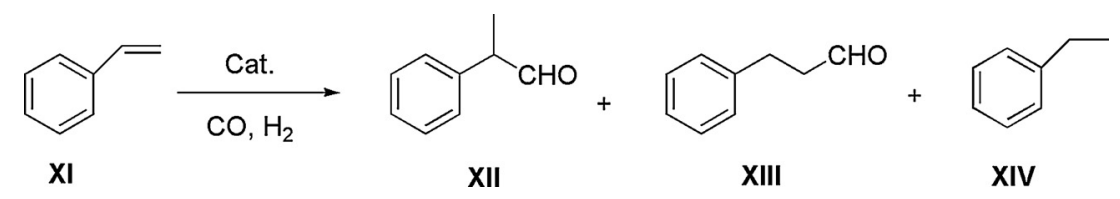

Scheme 4. Hydroformylation of styrene (XI).

obtained with complete selectivity (run 3 and 4, Table 3). In order to enhance the substrate conversion, we decided to maintain the mild reaction conditions adopted ( $\mathrm{T}$ and $\mathrm{P}$ ) but to prolong the reaction time up to $16 \mathrm{~h}$ : conversion of $\mathbf{V}$ was now practically complete affording the desired alcohol VI with total selectivity (run 5, Table 3). Same results were obtained in two consecutive recycling experiments but when the catalyst was reused for the third time conversion was only 71\%; despite the lower conversion, again FOL was selectively obtained (run 8 , Table 3 ). A comparison of Rh(DHTANa) activity with other catalytic systems is rather difficult as most of the homogeneous catalysts used in this reaction are based on ruthenium instead of rhodium and they all are active in organic solvent. For example, $\mathrm{Ru}(\mathrm{TMHD})_{3} \quad(\mathrm{TMHD}=2,2,6,6-$ tetramethyl-3,5-heptanedione) selectivity reduces FAL to FOL in THF at $80^{\circ} \mathrm{C}$ and $2.8 \mathrm{MPa}$ of $\mathrm{H}_{2}$ but using a $100 / 1$ substrate/Ru molar ratio [40], while $\mathrm{RuCl}_{2}\left(\mathrm{PPh}_{3}\right)_{3}$ selectively produces FOL in $3 \mathrm{~h}$ at $70^{\circ} \mathrm{C}$ and $3 \mathrm{MPa}$ of $\mathrm{H}_{2}$ in the presence of a relevant amount of catalyst (substrate/catalyst molar ratio $=39 / 1$ ) [41]. Also ruthenium(II)-bis(diimine) complexes are very active and selective in the hydrogenation of FAL to FOL in EtOH at $90-130^{\circ} \mathrm{C}$ and 1-5 MPa of hydrogen pressure with the catalyst ranging from 0.4 to $1 \mathrm{~mol} \%$ [42]. Very interestingly, ruthenium-carbene complexes selectively reduces FAL to FOL by transfer hydrogenation at $60^{\circ} \mathrm{C}$ in $24 \mathrm{~h}$ but, in this case, the H-donor $i$-propanol inevitably produces acetone as by-product [43]. At the light of these results we can assert that not only Rh(DHTANa) is active in the green solvent water but it is able to hydrogenate FAL to FOL at mild reaction conditions and by using a rather low substrate/Rh molar ratio (500/1).

As also ( $R$ )-thioctic acid is readily commercial available, we used the sodium salt of its reduced form, (R)-DHTANa, in the hydrogenation of acetophenone (IX), in order to evaluate both activity and enantioselectivity of the rhodium catalyst modified with this ligand (Scheme 3).

The reaction was carried out using water as the sole reaction solvent because of the fine miscibility of the substrate. Preliminary results were carried out at $60^{\circ} \mathrm{C}$ and $2 \mathrm{MPa}$ of $\mathrm{H}_{2}$ for $20 \mathrm{~h}$ with a substrate/Rh molar ratio of 500/1: in this case conversion to 1-phenylethanol $(\mathbf{X})$ was quite good (70\%) but the enantioselectivity to the (R)-isomer was really disappointing, being only $15 \%$ (run 1, Table 4); moreover, in this case, the catalytic precursor did not demonstrate to be a robust system showing a strong decrease of both conversion and enantioselectivity in two consecutive recycling experiments (run 2 and 3, Table 4). Also carrying out the reaction at the above reaction conditions but with a 100/1 substrate/Rh molar ratio, the only positive result was a conversion enhancement but the enantiomeric excess was very low (run 4 , Table 4).

Finally we evaluated the activity of Rh(DHTANa) also in the hydroformylation of styrene (XI), chosen as model substrate (Scheme 4). Hydroformylation is one of the most important industrial reactions catalyzed by soluble metal complexes [44-46]. The most efficient catalysts in terms of both activity and selectivity are rhodium complexes, capable to operate under mild conditions [46]. In order to overcome the drawback of the separation of the expensive catalyst from the product mixture, liquid-liquid two-phase systems have been studied and developed $[1,47]$. In particular, the use of environmentally more benign solvents such as water has been developed [1-3,47] and the hydroformylation process represents one of the most striking example of this catalytic methodology [1-3,46-51]. Since $1984, C_{4}$ and $C_{5}$ aldehydes from propene or butene are produced by using the aqueous biphasic OXEA process (former Ruhrchemie/Rhône-Poulenc) catalyzed by the water soluble complex Rh/TPPTS (TPPTS = triphenylphosphine3,3',3'-trisulfonic acid trisodium salt) [48-51]. Besides phosphines as TPPTS, many other new ligands and/or surfactants having different hydrophilic groups such as $-\mathrm{COOH}, \mathrm{NR}_{3},-\mathrm{OH}$, etc. have been designed to prepare new water soluble catalytic precursors $[1-3,47]$.

The reaction of styrene with $\mathrm{Rh}(\mathrm{DHTANa})$ was carried out at $80^{\circ} \mathrm{C}$ and $8 \mathrm{MPa}$ of syngas $\left(\mathrm{CO} / \mathrm{H}_{2}=1 / 1\right)$ by using a substrate/ $\mathrm{Rh}$ molar ratio of 1000/1: after $18 \mathrm{~h}$ conversion was practically quantitative and the branched aldehyde $\mathbf{X I I}$, as expected, was the prevailing product [46], obtained with $85 \%$ selectivity (run 1, Table 5): both catalyst activity and selectivity maintained unchanged in three recycling experiments (run 2-4, Table 5). Very interestingly, some experiments were carried out also in the presence of the catalytic system containing two moles of DHTANa per rhodium atom [ $\left.\mathrm{Rh}(\mathrm{DHTANa})_{2}\right]$ : the first reaction gave a conversion practically negligible (4\%), affording the only branched aldehyde XII (run 5, Table 5), but in three consecutive recycling experiments conversions were practically quantitative and selectivities to 2-phenylpropanal (XII) very close to those previously observed in presence of the catalytic system $\mathrm{Rh}$ (DHTANa) (Rh/DHTANa 1/1) (run 6-8, Table 5): on the base of these results we can suppose that, under the reaction conditions adopted, a molecule of DHTANa can dissociate rendering available two possible coordination sites on the rhodium atom so making easier the addition of both $\mathrm{CO}$ and $\mathrm{H}_{2}$ to smoothly complete the hydroformylation catalytic cycle. In all the experiments ethylbenzene was never detected in the reaction mixture. Despite the organic phase, after the first recycle experiment (run 6, Table 5), appeared practically colorless, the increase of activity, in principle, could be due to the rhodium leaching. With the aim to evaluate a possible leaching phenomenon, the organic phase was used as catalyst for the homogeneous hydrogenation of undec-1-ene in toluene: after $18 \mathrm{~h}$ at $80^{\circ} \mathrm{C}$ and $8 \mathrm{MPa}$ of hydrogen, undecane was formed in negligible amount (1\%) so excluding a relevant rhodium leaching. It is worth to note that the new catalyst $\mathrm{Rh}(\mathrm{DHTANa})$ works efficiently without the requirement of an excess of the water-soluble thioligand, so making this catalytic system even more sustainable.

\section{Conclusions}

The preliminary results presented in this communication show that Rh(DHTANa) seems to be an interesting new water-soluble and recyclable catalyst for hydrogenation and hydroformylation reactions, with fine-excellent chemo- and regio-selectivity, at least in the studied application, so spurring us to extend the study for knowing its applicability and limits in some relevant industrial processes. Noteworthy, this new catalyst showed to be quite robust and, on the contrary of the most common water-soluble catalytic systems, no ligand excess is required for its activity and recyclability. Furthermore, our approach to study simple, lowmolecular weight, commercial available and cheap thiocompounds 
for preparing new and promising water-soluble catalysts is, in our opinion, fruitful for sustainable applications.

\section{Acknowledgement}

We are grateful to Dr. Laura Sperni (Ca' Foscari University-Venice) for GC-MS analyses.

\section{References}

[1] B. Cornils, W.A. Herrmann, I.T. Horvath, W. Leitner, S. Mecking, H. OlivierBourbigou, D. Vogt (Eds.), Multiphase Homogeneous Catalysis, Wiley-VCH, Weinheim, 2005.

[2] F. Joò (Ed.), Aqueous Organometallic Catalysis, Kluwer Acad. Publ., Dordrecht, 2001.

[3] B. Cornils, W.A. Herrmann (Eds.), Aqueous-Phase Organometallic Catalysis, 2nd ed., Wiley-VCH, Weinheim, 2004.

[4] M. Lamblin, L. Nassar-Hardy, J.-C. Hierso, E. Fouquet, F.-X. Felpin, Adv. Synth. Catal. 352 (2010) 33-79.

[5] N. Zhang, F. Li, Q.J. Fu, S.C. Tsang, React. Kinet. Catal. Lett. 71 (2000) 393-404.

[6] E. Guibal, Prog. Polym. Sci. 30 (2005) 71-109.

[7] J. Steinreiber, T.R. Ward, Coord. Chem. Rev. 252 (2008) 751-766.

[8] M. Marchetti, F. Minello, S. Paganelli, O. Piccolo, Appl. Catal. A: Gen. 373 (2010) 76-80.

[9] H. Mao, X. Liao, B. Shi, Catal. Commun. 16 (2011) 210-214.

[10] M. Marchetti, G. Mangano, S. Paganelli, C. Botteghi, Tetrahedron Lett. 41 (2000) 3717-3720.

[11] M. Marchetti, S. Paganelli, Chim. Ind. 10 (2005) 44-46.

[12] C. Bertucci, C. Botteghi, D. Giunta, M. Marchetti, S. Paganelli, Adv. Synth. Catal. 344 (2002) 556-562.

[13] S. Crobu, M. Marchetti, G. Sanna, J. Inorg. Biochem. 100 (2006) 1514-1520.

[14] S. Paganelli, M. Marchetti, M. Bianchin, C. Bertucci, J. Mol. Catal. A: Chem. 269 (2007) 234-239.

[15] S.G. Murray, F.R. Hartley, Chem. Rev. (1981) 365-414.

[16] Bresson, B. Kalck, P. Thorez, A. Rhône-Poulenc Chimie de Base, US 4,778,905. 1988.

[17] D. Sellmann, J. Kappler, M. Moll, J. Am. Chem. Soc. 115 (1993) 1830-1835.

[18] N. Ruiz, A. Aaliti, J. Fornies-Camer, A. Ruiz, C. Claver, C.J. Cardin, D. Fabbri, S. Gladiali, J. Organomet. Chem. 545-546 (1997) 79-87.

[19] S. Gladiali, D. Fabbri, L. Kollar, C. Claver, N. Ruiz, A. Alvarez-Larena, J.F. Piniella, Eur. J. Inorg. Chem. (1998) 113-118.

[20] Z. Freixa, E. Martin, S. Gladiali, J.C. Bayon, Appl. Organometal. Chem. 14 (2000) 57-65.

[21] S. Rojas, J.L. García Fierro, R. Fandos, A. Rodríguez, P. Terreros, J. Chem. Soc., Dalton Trans. (2001) 2316-2324.
[22] N. Khiar, R. Navas, E. Álvarez, I. Fernández, ARKIVOC (2008) 211-224.

[23] S. Kundu, B.E.R. Snyder, A.P. Walsh, W.W. Brennessel, W.D. Jones, Polyhedron 58 (2013) 99-105.

[24] S. Di Dio, M. Marchetti, S. Paganelli, O. Piccolo, Appl. Catal. A: Gen. 399 (2011) 205-210.

[25] H.T. Uyeda, I.L. Medintz, J.K. Jaiswal, S.M. Simon, H. Mattoussi, J. Am. Chem. Soc. 127 (2005) 3870-3878.

[26] R. Banerjee (Ed.), Redox Biochemistry, Wiley-VCH, Weinheim, 2007.

[27] J.Q. Bond, D.M. Alonso, D. Wang, R.M. West, J.A. Dumesic, Science 327 (2010) 1110-1114.

[28] X.H. Zhang, T.J. Wang, L.L. Ma, C.Z. Wu, Fuel 89 (2010) 2697-2702.

[29] K. Yan, A. Chen, Fuel 115 (2014) 101-108.

[30] S. Sitthisa, T. Sooknoi, Y. Ma, P.B. Balbuena, D.E. Resasco, J. Catal. 277 (2011) $1-13$.

[31] D. Vargas-Hernández, J.M. Rubio-Caballero, J. Santamaria-Gonzalez, R. Moreno-Tost, J.M. Merida-Robles, M.A. Perez-Cruz, A. Jimenez-Lopez, R. Hernandez-Huesca, P. Maireles-Torres, J. Mol. Catal. A: Chem. 383-384 (2014) 106-113.

[32] P.D. Vaidya, V.V. Mahajani, Ind. Eng. Chem. Res. 42 (2003) 3881-3885.

[33] H. Li, S. Zhang, H. Luo, Mater. Lett. 58 (2004) 2741-2746.

[34] C. Xu, L. Zheng, D. Deng, J. Liu, S. Liu, Catal. Commun. 12 (2011) 996-999.

[35] A. Corma, S. Iborra, A. Velty, Chem. Rev. 107 (2007) 2411-2502.

[36] M.M. Villaverde, N.M. Bertero, T.F. Garetto, A.J. Marchi, Catal. Today 213 (2013) 87-92.

[37] H.Y. Zheng, Y.L. Zhu, B.T. Teng, Z.Q. Bai, C.H. Zhang, H.W. Xiang, Y.W. Li, J. Mol. Catal. A: Chem. 246 (2006) 18-23.

[38] X. Chen, H. Li, H. Luo, M. Qiao, Appl. Catal. A: Gen. 233 (2002) 13-20.

[39] R. Herbois, S. Noël, B. Lèger, L. Bai, A. Roucoux, E. Monflier, A. Ponchel, Chem. Commun. 48 (2012) 3451-3453.

[40] M.D. Bhor, A.G. Panda, Tetrahedron Lett. 49 (2008) 6475-6479.

[41] F. Huang, W. Li, Q. Lu, X. Zhu, Chem. Eng. Technol. 33 (2010) 2082-2088.

[42] A.S. Gowda, S. Parkin, F.T. Ladipo, Appl. Organometal. Chem. 26 (2012) 86-93.

[43] Z. Strassberger, M. Mooijman, E. Ruijter, A.H. Alberts, C. de Graaff, R.V.A. Orru, G. Rothenberg, Appl. Organometal. Chem. 24 (2010) 142-146.

[44] B. Cornils, W.A. Herrmann, M. Rasch, Angew. Chem. Int. Ed. Engl. 33 (1994) 2144.

[45] B. Cornils, W.A. Herrmann (Eds.), Applied Homogeneous Catalysis with Organometallic Compound, Wiley-VCH, Weinheim, 2000.

[46] P.W.N.M. van Leeuwen, C. Claver (Eds.), Rhodium Catalyzed Hydroformylation, Kluver Academic Publishers, Dordrecht, 2000.

[47] D. Cole-Hamilton, R. Tooze (Eds.), Catalyst Separation, Recovery and Recycling, Springer, Dordrecht, 2006.

[48] E.G. Kuntz, Chem. Technol. 17 (1987) 570-575.

[49] B. Cornils, E.G. Kuntz, J. Organomet. Chem. 502 (1995) 177-186.

[50] B. Cornils, Org. Process Res. Dev. 2 (1998) 121-127.

[51] E. Kuntz, (Rhône-Poulenc Ind.), Fr. Pat. 2314910 (1975); DE 2627354 (1976). 